\title{
Ministério Público: Velha instituição com novas
} funções?

Public Prosecutor: An Old Institution with New Functions?

Ministère Public: vieille institution aux nouvelles fonctions?

\section{Ludmila Mendonça Lopes Ribeiro}

\section{OpenEdition}

\section{Journals}

Edição electrónica

URL: http://journals.openedition.org/rccs/6654

DOI: $10.4000 /$ rccs. 6654

ISSN: 2182-7435

\section{Editora}

Centro de Estudos Sociais da Universidade de Coimbra

Edição impressa

Data de publição: 1 Setembro 2017

Paginação: 51-82

ISSN: 0254-1106

Refêrencia eletrónica

Ludmila Mendonça Lopes Ribeiro, « Ministério Público: Velha instituição com novas funções? », Revista Crítica de Ciências Sociais [Online], 113| 2017, colocado online no dia 27 julho 2017, criado a 19 abril 2019. URL : http://journals.openedition.org/rccs/6654; DOI : 10.4000/rccs.6654 


\title{
LUDMILA MENDONÇA LOPES RIBEIRO
}

\section{Ministério Público: \\ Velha instituição com novas funções?}

\begin{abstract}
Neste artigo analisamos os resultados de uma pesquisa quantitativa realizada com membros do Ministério Público (MP) brasileiro, a fim de responder a três perguntas: quem são os membros do MP?, o Ministério Público merece o título de "guardião da democracia"?, os membros do MP são promotores da ação penal ou verdadeiros agentes garantidores de uma sociedade mais justa? Os resultados indicam que os membros do MP fazem parte da elite brasileira, centram a sua ação no processo penal, com absorção da função de garantia de direitos difusos, coletivos e individuais homogêneos. Além disso, primam por uma atuação de gabinete em detrimento de um envolvimento efetivo com as demandas da população hipossuficiente. Trata-se, então, de uma velha instituição que não assumiu efetivamente as novas funções que lhe foram concedidas com a redemocratização.
\end{abstract}

Palavras-chave: Brasil; democracia; Ministério Público; sociologia do direito.

\section{Introdução}

Em 13 de março de 2016, milhares de indivíduos foram às ruas das capitais brasileiras protestar contra a situação política do país. Uma das bandeiras era “\#soqueremosoMP", uma clara alusão à qualidade do trabalho do Ministério Público, que seria superior às demais agências responsáveis pela administração da justiça no Brasil. Este movimento não é novo. Nas Jornadas de Junho de 2013, milhares de manifestantes pediram que a PEC 37, ${ }^{1}$ também chamada de PEC da Impunidade, fosse retirada da pauta de votação do Congresso Nacional. A sociedade brasileira credita ao MP elevado grau de confiança (49\%), muito superior ao da Polícia (25\%)

\footnotetext{
${ }^{1}$ A Proposta de Emenda à Constituição (PEC) n. ${ }^{\circ} 37$ tinha como objetivo estabelecer a exclusividade das polícias na investigação de delitos, retirando do Ministério Público a competência suplementar nesta seara. Para um melhor entendimento de como o MP se posicionou contra essa medida, ver: http://www.mppr.mp.br/modules/conteudo/conteudo.php? conteudo=4892, consultado a 09.12.2016.
} 
e do Poder Judiciário (35\%), como atesta o Índice de Confiança na Justiça da Fundação Getulio Vargas (Cunha et al., 2014).

O elevado grau de credibilidade e legitimidade que o Ministério Público possui é resultado de sua configuração como "quarto poder" (Arantes, 1999). A Constituição Federal da República de 1988 (CR/1988) conferiu aos promotores e procuradores de justiça atribuições que incluem, além da acusação criminal e da possibilidade de investigação penal, o controle externo da atividade policial, a supervisão da execução da pena privativa de liberdade, a proteção e garantia dos direitos difusos, coletivos e individuais homogêneos. A expectativa que a recepção das novas funções despertava nos membros do MP foi demonstrada em distintos levantamentos acadêmicos (Sinhoretto, 2011), sendo que em todos eles a instituição era vista como a responsável por institucionalizar ${ }^{2}$ as promessas da democracia brasileira.

Neste estudo, apresentamos um novo retrato do Ministério Público, a partir de três questionamentos direcionados aos próprios membros da instituição: a) quem são os membros do MP? b) o Ministério Público merece o título de "guardião da democracia"? e c) os membros do MP são promotores da ação penal ou verdadeiros agentes garantidores de uma sociedade mais justa?

\section{O Ministério Público na nova ordem constitucional}

A origem do Ministério Público remete ao absolutismo francês do século XIV, "quando funcionários reais ganharam prerrogativa para agir em nome da monarquia e na acusação de criminosos comuns" (Paula, 2010: 74). Por isso, na maioria dos países, as funções exercidas por essa agência estão associadas à acusação pública de alguém pela prática de um determinado delito. Têm crescido, porém, os arranjos institucionais que ampliam as atribuições tradicionais deste órgão. Para Gershman (1992), a ênfase na prevenção do delito fez com que as funções dos promotores norte-americanos fossem substantivamente alteradas, aumentando o prestígio e poder da categoria vis-à-vis a ausência de mecanismos de controle interno e externo. Todavia, mesmo nesta localidade, a atuação do promotor se concentra na área penal.

A singularidade do MP brasileiro reside na possibilidade de a sua atuação transcender a seara criminal (Sadek, 1997), englobando temáticas tão diversas

\footnotetext{
${ }^{2}$ Empregamos a palavra institucionalizar no sentido que Bourdieu (1998: 101) atribui ao termo, ou seja, como um processo que permite "a objetivação e a incorporação como acumulação nas coisas e nos corpos de um conjunto de conquistas históricas, que trazem a marca das suas condições de produção e que tendem a gerar as condições da sua própria reprodução (quanto mais não seja pelo efeito de demonstração e imposição das necessidades que um bem exerce unicamente pela sua existência), aniquila continuamente possíveis laterais".
} 
como o controle da atividade policial, a supervisão da pena privativa de liberdade e a proteção e garantia dos direitos difusos, coletivos e individuais homogêneos ${ }^{3}$ (Cardia et al., 1998).

A conformação organizacional do MP brasileiro é consequência de um movimento iniciado na transição do autoritarismo para a democracia, que buscava o maior acesso à justiça para a população mais pobre (Paula, 2010). Ao longo da ditadura militar (1964-1985), o promotor de justiça era responsável pelo atendimento jurídico da população hipossuficiente, sendo evidente como os indivíduos que viviam em contextos de desvantagem concentrada sofriam com a ausência de determinados serviços públicos e com a violência de agentes públicos. Nessa época, o MP era um órgão especializado do Poder Executivo, como ocorre nos demais países (Kerche, 2007).

Durante a constituinte, os promotores de justiça passam a reivindicar uma atuação mais expressiva por parte do $\mathrm{MP}$, argumentando que esse deveria ter atribuições mais amplas do que a acusação penal. O resultado dessa mobilização foi a sua consagração como instituição autônoma e independente no capítulo "Das funções essenciais à Justiça" da CR/1988 (Cardia et al., 1998: 189). É a partir deste momento que o Ministério Público passa a ter a responsabilidade de defesa da ordem jurídica, do regime democrático e dos interesses sociais e individuais indisponíveis (art. 127 da CR /1988), o que ampliou as competências do MP para além da titularidade da ação penal pública (art. 129). ${ }^{4}$

\footnotetext{
${ }^{3}$ De acordo com Silva (2001: 141), "Interesses e direitos individuais homogêneos podem ser definidos como direitos individuais que, em função da inserção do indivíduo em determinado contexto social, criam um núcleo comum de questões de direito ou de fato entre os sujeitos, como, por exemplo, o direito de cada criança à matrícula em escolas públicas. Interesses e direitos coletivos são interesses comuns a uma coletividade de pessoas, tais como os interesses que reúnem os moradores de um conjunto residencial. Interesses e direitos difusos, por sua vez, referem-se a grupos menos determinados de pessoas, não ligadas, necessariamente, por um vínculo de direito ou de fato preciso, como no caso dos consumidores de determinado bem lesados pela empresa que o produziu.".

${ }^{4}$ CR/1988, art. 129. São funções institucionais do Ministério Público: I - promover, privativamente, a ação penal pública, na forma da lei; II - zelar pelo efetivo respeito dos Poderes Públicos e dos serviços de relevância pública aos direitos assegurados nesta Constituição, promovendo as medidas necessárias à sua garantia; III - promover o inquérito civil e a ação civil pública, para a proteção do patrimônio público e social, do meio ambiente e de outros interesses difusos e coletivos; IV - promover a ação de inconstitucionalidade ou representação para fins de intervenção da União e dos Estados, nos casos previstos nesta Constituição; V - defender judicialmente os direitos e interesses das populações indígenas; VI - expedir notificações nos procedimentos administrativos de sua competência, requisitando informações e documentos para instruí-los, na forma da lei complementar respectiva; VII - exercer o controle externo da atividade policial, na forma da lei complementar mencionada no artigo anterior; VIII - requisitar diligências investigatórias e a instauração de inquérito policial, indicados os fundamentos jurídicos de suas manifestações processuais; IX - exercer outras funções que lhe forem conferidas, desde que compatíveis com sua finalidade, sendo-lhe vedada a representação judicial e a consultoria jurídica de entidades públicas.
} 
A nova institucionalidade do MP incluiu a criação e o reconhecimento de inovadores instrumentos jurídicos (como a Ação Civil Pública) ${ }^{5}$ e extrajudiciais (como o Inquérito Civil ${ }^{6}$ e o Termo de Ajustamento de Conduta), ${ }^{7}$ indispensáveis à garantia dos direitos dos hipossuficientes. Essas alterações trouxeram implicações práticas para o funcionamento do MP, que passou a gozar de maior independência com relação aos Poderes Executivo, Legislativo e Judiciário, autonomia administrativa e funcional, sem a previsão de qualquer mecanismo de accountability (Sadek, 2002). ${ }^{8}$

Desde a CR/1988, o Ministério Público brasileiro organiza-se em dois ramos principais: o da União (MPU) e o dos estados (MPE). Duas são as diferenças existentes entre eles: a institucionalidade da justiça em questão - se federal ou estadual - e a temática, posto que trabalho e militar são atribuições exclusivas do MPU, enquanto os MPEs trabalham com uma miríade de assuntos, excluindo o direito do trabalho ou militar.

O Ministério Público da União (MPU) divide-se em quatro ramos: Federal, Militar, Trabalho e Ministério Público do Distrito Federal e dos Territórios. Perante o Superior Tribunal de Justiça (STJ) e o Supremo Tribunal Federal (STF), somente podem atuar os seus integrantes (Sadek, 1997: 6). Todos os membros MPU são denominados procuradores.

O Ministério Público dos Estados (MPE) corresponde às unidades da federação, somando 26 instituições. Seus membros são denominados promotores, quando exercem suas funções perante os juízes estaduais; ou procuradores, quando atuam na segunda instância perante um colégio de desembargadores. Ou seja, no MPE ser procurador ou promotor é uma diferenciação que ocorre de acordo com a etapa em que o profissional se encontra na carreira.

A abertura do sistema de justiça às demandas populares multiplicou as atribuições dos membros do MP, levando à realização de novos

\footnotetext{
5 "A ação civil pública é um instrumento jurídico que permite a representação, junto ao Poder Judiciário, de interesses coletivos, difusos e individuais homogêneos” (Kerche, 2007: 274).

6 "Procedimento administrativo que possibilita a investigação e o recolhimento de provas e elementos que convençam o promotor da necessidade ou não de propor uma ação civil pública" (Silva, 2001: 133). "O inquérito civil permite que as investigações sejam conduzidas e coordenadas pelos promotores, sendo que eles podem decidir independentemente de outro ator estatal se o caso merece se transformar em uma ação civil pública" (Kerche, 2008: 276).

${ }^{7}$ Assinado entre o promotor de justiça e pessoas físicas ou jurídicas e autoridades públicas - assim, os destinatários "se comprometem a tomar iniciativas - quando caracterizada a omissão perante direitos - a reparar danos cometidos ou a deixar de praticar irregularidades. Caso descumpridos, estes acordos podem ser cobrados judicialmente" (Silva, 2001: 134).

${ }^{8}$ Somente em 2005 foi instituído o Conselho Nacional do Ministério Público (CNMP), um órgão de controle interno cuja atribuição é "a fiscalização da gestão administrativa e financeira, o controle da atuação dos promotores e procuradores de Justiça e a escolha de um corregedor nacional entre os membros que o integram” (Kerche, 2007: 270).
} 
concursos para a ampliação da quantidade de profissionais (Arantes, 1999). Como o ingresso na carreira é reservado aos bacharéis em Direito aprovados em um concurso de provas e títulos, cujas exigências e grau de dificuldade são elevados, a forma de seleção dos quadros é vista como uma barreira à incorporação dos segmentos mais populares nos quadros da instituição.

Esta forma de estruturação do Ministério Público contribui para que essa agência se institucionalize como um campo dentro do sistema de justiça, ${ }^{9}$ isto é, um espaço que estrutura regras, recursos e agentes com determinadas características, com o objetivo de exercer dominação. O campo é uma unidade analítica que Bourdieu (1998) construiu a partir da sociologia de Weber, já que a ossatura desse conceito se fundamenta na ideia de diferenciação da sociedade que, por seu turno, seria resultado da autonomização dos sistemas de ação. Almeida (2014: 82) argumenta que dentro do campo são "produzidas formas de dominação específicas, bem como se reproduzem formas de dominação próprias de outros campos sociais, que se traduzem na lógica específica de cada um desses espaços sociais".

Tratar o MP como um campo, no sentido que Bourdieu (1998) aplica ao termo, significa compreender como se dá o seu funcionamento, com especial ênfase em como são recrutados os seus membros e em que medida a posição de cada qual resulta da quantidade de capital acumulada em outros círculos para além do próprio MP. Essas características, por sua vez, podem ser vislumbradas no perfil dos operadores, na percepção que eles têm sobre as principais funções da instituição e, ainda, no estilo de trabalho. Entender o MP como um campo dentro do sistema de justiça e, fora dele, dentro do mundo político, significa compreender em que medida as regras e os recursos outorgados a essa instituição com a CR/1988 são operacionalizados.

Assim, por um lado, a transição democrática transformou o Ministério Público em "quarto poder" (Arantes, 1999: 100) em um campo autônomo em relação ao sistema de justiça, dado o recebimento de novas funções, que estenderam as suas atribuições de titular da ação penal ao campo político; mas por outro, a possibilidade de cuidar de uma miríade de funções se tornou uma espécie de "cheque em branco". Contudo, nem todos os promotores e procuradores preenchem o cheque da mesma forma, sendo que esse preenchimento é o que se pretende desvelar nas seções seguintes.

\footnotetext{
${ }^{9}$ Usamos aqui o entendimento que Sadek (1997: 237) tem de sistema de justiça, como "o conjunto de instituições estatais encarregadas de garantir os preceitos constitucionais, de aplicar a lei e de distribuir justiça”.
} 


\section{Metodologia}

Os dados analisados neste artigo são resultantes de uma pesquisa realizada pelo Centro de Estudos de Segurança e Cidadania (CESeC $)^{10}$ com promotores e procuradores de justiça entre fevereiro de 2015 e fevereiro de 2016.

De acordo com as informações repassadas pelo Conselho Nacional do Ministério Público (CNMP), em janeiro de 2015 o MP da União contava com 2270 membros e os MPs estaduais com 10056 membros, excluindo-se deste cálculo os servidores administrativos. Como se nota na Tabela 1 , a quantidade de membros do MPE e do MPU em cada estado da federação é bastante diversa, sendo que a taxa de promotores e procuradores de justiça por 100000 habitantes é uma boa medida desta desigualdade. Em média, o país conta com seis membros do MP para cada 100000 habitantes, sendo enorme a discrepância, dada a grande concentração de membros do MP no Distrito Federal (19 para cada 100000 habitantes) e a baixa concentração no Amazonas e no Pará, cada qual com quatro promotores ou procuradores para cada grupo de 100000 habitantes.

TABELA 1 - Quantidade de membros do Ministério Público Estadual (MPE) e do Ministério Público da União (MPU), por estado e por 100000 habitantes

\begin{tabular}{|c|c|c|c|}
\hline Estados & $\begin{array}{c}\text { Quantidade } \\
\text { de membros } \\
\text { do MPE }\end{array}$ & $\begin{array}{c}\text { Quantidade de } \\
\text { membros } \\
\text { do MPU }\end{array}$ & $\begin{array}{c}\text { Taxa } \\
\text { por } 100000 \\
\text { habitantes }\end{array}$ \\
\hline Acre & 69 & 6 & 9 \\
\hline Alagoas & 147 & 24 & 5 \\
\hline Amapá & 80 & 6 & 11 \\
\hline Amazonas & 167 & 28 & 5 \\
\hline Bahia & 559 & 84 & 4 \\
\hline Ceará & 362 & 81 & 5 \\
\hline Distrito Federal & $\begin{array}{r}\text { Não se } \\
\text { aplica }\end{array}$ & 556 & 19 \\
\hline Espírito Santo & 313 & 38 & 9 \\
\hline Goiás & 372 & 37 & 6 \\
\hline Maranhão & 301 & 36 & 5 \\
\hline
\end{tabular}

${ }^{10} \mathrm{O}$ relatório final desta pesquisa pode ser acessado em http://www.ucamcesec.com.br/livro/ ministerio-publico-guardiao-da-democracia-brasileira/. Consultado a 29.05.2017. 
cont.

\begin{tabular}{|c|c|c|c|}
\hline Estados & $\begin{array}{c}\text { Quantidade } \\
\text { de membros } \\
\text { do MPE }\end{array}$ & $\begin{array}{c}\text { Quantidade de } \\
\text { membros } \\
\text { do MPU }\end{array}$ & $\begin{array}{c}\text { Taxa } \\
\text { por } 100000 \\
\text { habitantes }\end{array}$ \\
\hline Mato Grosso & 216 & 41 & 8 \\
\hline Mato Grosso do Sul & 211 & 37 & 9 \\
\hline Minas Gerais & 993 & 118 & 5 \\
\hline Pará & 302 & 52 & 4 \\
\hline Paraíba & 204 & 33 & 6 \\
\hline Paraná & 673 & 105 & 7 \\
\hline Pernambuco & 391 & 73 & 5 \\
\hline Piauí & 160 & 36 & 6 \\
\hline Rio de Janeiro & 884 & 220 & 7 \\
\hline Rio Grande do Norte & 205 & 33 & 7 \\
\hline Rio Grande do Sul & 640 & 158 & 7 \\
\hline Rondônia & 135 & 24 & 9 \\
\hline Roraima & 47 & 16 & 12 \\
\hline Santa Catarina & 437 & 66 & 7 \\
\hline São Paulo & 1941 & 328 & 5 \\
\hline Sergipe & 134 & 23 & 7 \\
\hline Tocantins & 113 & 11 & 8 \\
\hline Total & 10056 & 2270 & 6 \\
\hline
\end{tabular}

Fonte: Quantidade de promotores e procuradores cedida pelo CNMP (2015). População: Projeção do IBGE para 2015.

Para alcançar essa diversidade de profissionais, foi organizada uma pesquisa on-line, aplicada em dois momentos. No primeiro, entre fevereiro e agosto de 2015, o CNMP enviou e-mails para a coordenação de cada MPU e MPE solicitando o encaminhamento do questionário aos seus membros. No segundo, entre setembro de 2015 e fevereiro de 2016, a coordenação da pesquisa enviou 1953 e-mails para os endereços cadastrados nas páginas web das instituições. A taxa de retorno foi de 7\%, com 899 questionários devidamente preenchidos. Outros 309 foram excluídos por não contarem com todas as respostas, inviabilizando comparações. 
Com vistas a garantir a representatividade dos resultados, a amostra de 899 questionários foi ponderada de acordo com o MP de origem (se União ou Estadual) e o estado da federação em que o profissional atua, posto que o MPE tem um peso maior do que o MPU e estados como São Paulo contam com mais profissionais do que o Amapá, por exemplo. Após a ponderação, a distribuição geográfica dos questionários refletiu a distribuição espacial dos membros do MP (Tabela 2).

TABELA 2 - Quantidade de membros do MP e questionários preenchidos,
por estado

\begin{tabular}{|c|c|c|c|c|}
\hline \multirow[t]{2}{*}{ Estados } & \multicolumn{2}{|c|}{$\begin{array}{l}\text { Total de promotores } \\
\text { e procuradores }\end{array}$} & \multicolumn{2}{|c|}{$\begin{array}{l}\text { Distribuição dos questionários } \\
\text { respondidos, após ponderação }\end{array}$} \\
\hline & $\mathrm{N}$ & $\%$ do total & $\mathrm{N}$ & $\%$ do total \\
\hline Acre & 75 & 1 & 5 & 1 \\
\hline Alagoas & 171 & 1 & 12 & 1 \\
\hline Amapá & 86 & 1 & 6 & 1 \\
\hline Amazonas & 195 & 2 & 14 & 2 \\
\hline Bahia & 643 & 5 & 47 & 5 \\
\hline Ceará & 443 & 4 & 32 & 4 \\
\hline Distrito Federal & 556 & 5 & 41 & 5 \\
\hline Espírito Santo & 351 & 3 & 26 & 3 \\
\hline Goiás & 409 & 3 & 30 & 3 \\
\hline Maranhão & 337 & 3 & 25 & 3 \\
\hline Mato Grosso & 257 & 2 & 19 & 2 \\
\hline Mato Grosso do Sul & 248 & 2 & 18 & 2 \\
\hline Minas Gerais & 1111 & 9 & 81 & 9 \\
\hline Pará & 354 & 3 & 26 & 3 \\
\hline Paraíba & 237 & 2 & 17 & 2 \\
\hline Paraná & 778 & 6 & 57 & 6 \\
\hline Pernambuco & 464 & 4 & 34 & 4 \\
\hline Piauí & 196 & 2 & 14 & 2 \\
\hline Rio de Janeiro & 1104 & 9 & 81 & 9 \\
\hline Rio Grande do Norte & 238 & 2 & 17 & 2 \\
\hline
\end{tabular}




\begin{tabular}{|c|c|c|c|c|}
\hline \multirow{2}{*}{ Estados } & \multicolumn{2}{|c|}{$\begin{array}{l}\text { Total de promotores } \\
\text { e procuradores }\end{array}$} & \multicolumn{2}{|c|}{$\begin{array}{l}\text { Distribuição dos questionários } \\
\text { respondidos, após ponderação }\end{array}$} \\
\hline & $N$ & $\%$ do total & $\mathrm{N}$ & $\%$ do total \\
\hline Rio Grande do Sul & 798 & 6 & 58 & 6 \\
\hline Rondônia & 159 & 1 & 12 & 1 \\
\hline Roraima & 63 & 1 & 5 & 1 \\
\hline Santa Catarina & 503 & 4 & 37 & 4 \\
\hline São Paulo & 2269 & 18 & 165 & 18 \\
\hline Sergipe & 157 & 1 & 11 & 1 \\
\hline Tocantins & 124 & 1 & 9 & 1 \\
\hline Total & 12326 & 100 & 899 & 100 \\
\hline
\end{tabular}

Fonte: Quantidade de promotores e procuradores cedida pelo CNMP. Quantidade de questionários computada pela pesquisa (CESeC).

O questionário aplicado possuía 37 questões, sendo 18 questões de perfil socioprofissional, cinco sobre funções do MP, quatro sobre controle da atividade policial, quatro sobre supervisão da execução da pena privativa de liberdade, sobre proteção e garantia dos direitos difusos, coletivos e individuais homogêneos e duas questões de avaliação da performance do sistema de justiça. Na próxima seção, expomos os resultados quantitativos obtidos com a pesquisa, sendo que os percentuais apresentados podem ter uma variação de um ponto para mais ou para menos.

\section{Quem são os membros do MP?}

Historicamente, as atividades relacionadas à aplicação da lei são ocupações masculinas, dado o entendimento de que a acusação e a decisão do destino de "criminosos" demandam características como "sangue frio" e desprendimento, que não estariam presentes nas mulheres (Kakar, 2002: 238). O Ministério Público brasileiro parece ser um reflexo dessa visão: $70 \%$ dos seus membros são homens. A título de comparação, o efetivo feminino das polícias brasileiras está em torno de 19\% (FBSP, 2016), percentual semelhante ao encontrado na magistratura (Vianna et al., 1997) e no próprio MP em 1990 (Castilho e Sadek, 1998: 6). Logo, nas últimas décadas, a instituição se abriu ao ingresso feminino, que aumentou em $10 \%$.

Os entrevistados se declararam brancos $(76,3 \%)$ quanto à cor da pele. No Censo de 2010, "os negros no Brasil, considerados aqueles que se declaram pardos e pretos, correspondiam a 96,7 milhões de indivíduos $-50,7 \%$ 
dos residentes" (Volpe et al., 2012:311), algo que não encontra ressonância dentro do MP, integrado majoritariamente por homens brancos: somente essa categoria responde por $53,3 \%$ do total de membros.

A sociologia das profissões ajuda a compreender esses resultados. Segundo esse aporte, "carreiras mais masculinas têm menor participação de pretos e pardos" (Vargas, 2010: 112), dada a forma como esses campos refletem a própria organização da sociedade. Apesar de o concurso ser aberto a todos, "são poucos os candidatos que desafiam a hierarquia não escrita nas carreiras" (ibidem: 114). Visto que o campo do MP se apresenta como hierarquicamente superior a outros do sistema de justiça, seus membros pertencem prioritariamente a um grupo de poder específico.

Em seu livro As profissões imperiais, Edmundo Campos Coelho (1999) descrevia os bacharéis em Direito como uma elite de homens brancos que possuíam um título e o ostentavam na parede, demarcando a sua posição em relação aos demais, que exerciam a atividade de maneira prática. Desde essa época, várias mudanças ocorreram no acesso aos cursos jurídicos no Brasil, o que facilitou a obtenção do diploma por uma gama de cidadãos que, na velha ordem, não teriam essa chance. Contudo,

em que pese o expressivo quantitativo de faculdades de Direito no país, a relação candidato/vaga nos cursos mais prestigiosos permanece elevada. Por outro lado, nem todos os graduados em Direito exercerão a profissão, dada a seleção da OAB. Aos selecionados e atuantes caberá um exercício profissional bastante auto-referido. (Vargas, 2010: 110)

Neste contexto, o concurso para o MP é a quarta barreira que os indivíduos devem transpor, se constituindo em uma atualização do peso que o diploma na parede tinha no Império. Trata-se de um concurso que reifica barreiras de classe: como os ditames para ingresso em cada um dos MPs são bastante rigorosos, existe elevada homogeneidade dos promotores e procuradores de justiça, algo especialmente visível na origem social desses sujeitos $-40 \%$ são procedentes de famílias em que o pai e a mãe possuem curso superior ou pós-graduação. $\mathrm{Na}$ população brasileira somente $6,5 \%$ dos indivíduos possuem diploma de nível superior (Comin e Barbosa, 2011).

Mais do que isso, os promotores e procuradores de justiça são, em boa medida, herdeiros dos bacharéis imperiais: $34 \%$ são filhos, netos ou sobrinhos de advogados. O MPE conta com um percentual maior de profissionais cujos ascendentes eram da carreira jurídica (35,6\%) do que o MPU (29,1\%). Em ambos os casos, a maioria dos pais, tios ou avós exercia a advocacia privada. 
Aparentemente, existe certo fechamento do recrutamento dentro de determinadas classes sociais, dada a "limitação" dos membros do MP a um determinado círculo estamental, o que pode levar ao fechamento endógeno das relações sociais (Weber, 1999: 181). Em outras palavras, o acesso ao campo do MP não é democrático, já que "a impermeável hierarquia interna entre as carreiras no Brasil parece se prolongar ao longo do tempo, abrindo pouco espaço para uma democratização do acesso a postos profissionais destacados" (Vargas, 2010: 120).

A maioria dos membros do MP ingressou na carreira entre os anos de 1988 e 2008, sendo que tão somente 6,6\% assumiram a profissão antes da CR/1988. Logo, a instituição tem passado por grande processo de renovação de seus quadros na nova ordem constitucional (Sadek, 1997; Castilho e Sadek, 1998), apesar dessa tendência ter se arrefecido nos últimos anos (Tabela 3).

TABELA 3 - Ano de ingresso no Ministério Público, por instituição de origem

\begin{tabular}{|c|c|c|c|c|c|c|}
\hline \multirow{2}{*}{\multicolumn{2}{|c|}{$\begin{array}{l}\text { A qual Ministério } \\
\text { Público o(a) Sr.(a) } \\
\text { está vinculado? }\end{array}$}} & \multicolumn{5}{|c|}{ Ano de ingresso no $M P$, em faixas } \\
\hline & & $\begin{array}{c}\text { Antes } \\
\text { de } 1988\end{array}$ & $\begin{array}{c}\text { Entre } \\
1988 \\
\text { e } 1998\end{array}$ & $\begin{array}{c}\text { Entre } \\
1999 \\
\text { e } 2008\end{array}$ & $\begin{array}{c}\text { Entre } \\
2009 \\
\text { e } 2016\end{array}$ & Total \\
\hline \multirow{2}{*}{ União } & $\mathrm{N}$ & 2 & 7 & 20 & 8 & 37 \\
\hline & $\%$ & 5,4 & 18,9 & 54,1 & 21,6 & 100,0 \\
\hline \multirow{2}{*}{ Estados } & $\mathrm{N}$ & 57 & 339 & 294 & 172 & 862 \\
\hline & $\%$ & 6,6 & 39,3 & 34,1 & 20,0 & 100,0 \\
\hline \multirow{2}{*}{ Total } & $\mathrm{N}$ & 59 & 346 & 314 & 180 & 899 \\
\hline & $\%$ & 6,6 & 38,5 & 34,9 & 20,0 & 100,0 \\
\hline
\end{tabular}

Qui-quadrado: ${ }^{11} 8,009(0,046)$.

Fonte: Ministério Público: guardião da democracia? (CESeC, 2016).

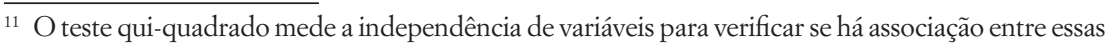
duas informações. No entanto não se pode estabelecer uma relação de causalidade, já que esse não é um teste apropriado. Ou seja, pode-se afirmar que os fenômenos estão relacionados, mas não se um causa o outro necessariamente. 
Os promotores e procuradores de justiça possuem uma idade média de 42,8 anos (com uma mediana de 43 anos), sendo que não existem diferenças de idade por sexo. É um perfil muito semelhante ao dos juízes, que no último levantamento apresentavam média de idade em torno de 42 anos (Vianna et al., 1997: 60), mas distinto do levantamento anterior de Sadek (1997), quando os membros do MP tinham idade média de 35 anos. Houve certo envelhecimento desses profissionais porque o ritmo de entrada de novos membros desacelerou.

As diferenças no perfil etário são significativas por lugar de trabalho. A Tabela 4 indica que quanto mais velho o sujeito, maior a probabilidade de ele realizar o seu trabalho na capital. A mudança geográfica, do interior para a capital, acontece em torno dos 40 anos de idade, o que pode ser explicado pela forma de estruturação da carreira.

TABELA 4 - Idade dos membros do MP, por local de atuação

\begin{tabular}{|c|c|c|c|c|c|c|c|}
\hline \multirow{2}{*}{\multicolumn{2}{|c|}{$\begin{array}{l}\text { Em termos } \\
\text { geográficos, } \\
\text { o(a) Sr.(a) atua: }\end{array}$}} & \multicolumn{6}{|c|}{ Ano de ingresso no MP, em faixas } \\
\hline & & $\begin{array}{c}\text { Até } \\
30 \text { anos }\end{array}$ & $\begin{array}{l}\text { Entre } 31 \\
\text { e } 36 \text { anos }\end{array}$ & $\begin{array}{l}\text { Entre } 37 \\
\text { e } 42 \text { anos }\end{array}$ & $\begin{array}{l}\text { Entre } 43 \\
\text { e } 49 \text { anos }\end{array}$ & $\begin{array}{l}\text { Acima de } \\
50 \text { anos }\end{array}$ & Total \\
\hline \multirow{2}{*}{$\begin{array}{l}\mathrm{Na} \\
\text { capital }\end{array}$} & N & 5 & 45 & 104 & 126 & 167 & 447 \\
\hline & $\%$ & 1,1 & 10,1 & 23,3 & 28,2 & 37,4 & 100,0 \\
\hline \multirow{2}{*}{$\begin{array}{l}\text { No } \\
\text { interior }\end{array}$} & N & 31 & 151 & 111 & 94 & 64 & 451 \\
\hline & $\%$ & 6,9 & 33,5 & 24,6 & 20,8 & 14,2 & 100,0 \\
\hline \multirow{2}{*}{ Total } & N & 36 & 196 & 215 & 220 & 231 & 899 \\
\hline & $\%$ & 4,0 & 21,8 & 23,9 & 24,5 & 25,7 & 100,0 \\
\hline
\end{tabular}

Qui-quadrado: $126,898(0,000)$.

Fonte: Ministério Público: guardião da democracia? (CESeC, 2016).

Os promotores iniciam as suas atividades em cidades pequenas, o que ocorre também com os procuradores da União, dado o processo de interiorização da instituição (Castilho e Sadek, 1998: 26). Nesta etapa, o profissional atua "na chamada 'clínica geral', isto é, cuidando de processos relacionados a todas as áreas" (Silva, 2001: 131), o que tem como vantagem fazer com que 
o operador entenda que a sua principal função é o atendimento ao público. Depois de alguns anos, dependendo das vagas existentes para remoção, o indivíduo pode se candidatar para o trabalho em outras cidades. A vantagem dessa mudança é a possibilidade de especialização, um trabalho focalizado em poucas áreas temáticas em detrimento da "clínica geral". Após quase uma década de serviço, o sujeito "tem a chance de se candidatar aos cargos mais especializados do Ministério Público e de 'perseguir promoções' até ter condições de galgar o último degrau da carreira" (ibidem), quando é transferido para a capital ou região metropolitana (no caso do MPE) ou para Brasília (no caso do MPU).

Atualmente, 67,6\% dos procuradores de justiça da União estão lotados nas capitais e regiões metropolitanas, enquanto 50,9\% dos membros dos MPs estaduais se encontram no interior. No caso do MPE, apesar de vários promotores já fazerem jus à remoção para capital, visto que a renovação dos quadros se arrefeceu nos últimos anos, eles ainda estão lotados nas cidades do interior.

Os entrevistados optaram pela profissão de promotor ou procurador pouco tempo após a graduação em Direito (em média, 4 anos). A aprovação no concurso aconteceu quando o sujeito era bastante jovem: em média com 29 anos (mediana de 28 anos), indicando que a preparação para o concurso é feita durante o bacharelado. ${ }^{12}$ Não resta dúvida de que a opção pela carreira pública ocorre em tenra idade, provavelmente em razão da influência e apoio das famílias, que podem custear os estudos de seus membros enquanto esses não são aprovados no concurso.

Apesar de os promotores e procuradores ingressarem no MP ainda muito jovens (26 anos em média), a maioria conta com algum tipo de experiência profissional anterior. Entre as ocupações exercidas estão a advocacia privada (44\%), as atividades de serventuário da justiça estadual e federal (25\%) e outras ocupações não jurídicas (22\%). É bom lembrar que, até 2010, boa parte dos MPs estaduais não exigia o exercício da advocacia por um tempo mínimo e, por isso, ter trabalhado antes não era um pré-requisito para o concurso, o que explica a ausência de experiência profissional entre $9,7 \%$ dos entrevistados.

Como a opção pela carreira pública pode decorrer da competição e da dificuldade de se encontrar uma boa posição no mercado privado de advogados (como observado em Vianna et al. (1997) para os magistrados brasileiros), pedimos para os entrevistados apontarem os cinco motivos determinantes da opção pelo concurso do MP (Tabela 5).

${ }_{12}$ Esses resultados são semelhantes aos encontrados por Vianna et al. (1997) para a composição da magistratura e por Castilho e Sadek (1998) para o Ministério Público Federal. 
TABELA 5 - Distribuição percentual dos cinco principais motivos que levaram ao ingresso no Ministério Público

\begin{tabular}{lcc}
\hline Motivo & N & $\%$ \\
\hline Realização de justiça & 879 & 97,9 \\
\hline Estabilidade do cargo & 823 & 91,6 \\
\hline Atuação no combate à criminalidade & 669 & 74,5 \\
\hline Remuneração & 667 & 74,2 \\
\hline Proteção da população de baixa renda & 577 & 64,2 \\
\hline Prestígio/reconhecimento & 393 & 43,7 \\
\hline Foi o primeiro concurso em que fui aprovado & 146 & 16,2 \\
\hline Parentes na carreira & 41 & 4,6 \\
\hline
\end{tabular}

Fonte: Ministério Público: guardião da democracia? (CESeC, 2016).

Em primeiro lugar aparece a realização da justiça (98\%), seguida pela estabilidade garantida pelo emprego público ( $92 \%)$. Esses resultados diferem dos encontrados por Azevedo (2010) para o Ministério Público Federal, quando a estabilidade aparecia como a motivação principal. No entanto, em ambos os casos o concurso público é visto como uma forma de aliviar as incertezas que a advocacia privada apresenta. São, portanto, indivíduos que se veem como vocacionados para o exercício das funções de bacharel em Direito, mas não desejam ter de "lutar pela sobrevivência" diariamente em um escritório (ibidem).

Quase todos os entrevistados marcaram a opção "realização da justiça", o que pode ser visto como a resposta socialmente desejável de membros de uma instituição inscrita na ordem constitucional como essencial para a administração da justiça. Do ponto de vista sociológico, essa afirmação aciona uma série de curiosidades sobre o que essa 'justiça' pode significar: se apenas acusar publicamente aqueles que cometeram um crime, ou se trabalhar para a construção de políticas públicas que garantam maior equidade entre indivíduos distintos. A primeira hipótese explicativa parece se apresentar como vitoriosa, já que a "atuação no combate à criminalidade" foi mencionada como motivo por $75 \%$ dos entrevistados, em detrimento de "proteção da população de baixa renda", que aparece com um percentual menor de menções do que a "remuneração" (64\% versus $74 \%$, respectivamente). Então, na próxima seção investigamos se o MP tem atuado para a institucionalização da democracia no Brasil. 


\section{O Ministério Público merece o título de "guardião da democracia"?}

Qualificar o Ministério Público como "guardião da democracia" é atribuir-lhe missões que vão desde a vocalização de demandas sociais até à fiscalização da justa aplicação da lei (Arantes, 1999). Para compreender como os membros dos MPs percebiam esse direcionamento geral, eles deveriam se posicionar entre concordar totalmente e discordar totalmente diante de oito assertivas distintas.

As afirmações que serviram de base para essa questão foram elaboradas a partir de Sadek (1997) - primeira a mapear as mudanças introduzidas pela CR/1988 e as expectativas dos promotores estaduais em relação às suas novas atividades - e Azevedo (2010), que delineou o entendimento dos procuradores federais quanto a essas alterações. Em ambos os estudos, a maior aspiração era de que o MP se tornasse um ator de destaque na construção da democracia, apesar da dificuldade de seus membros em conjugar as expectativas legais com a realidade do serviço prestado. Vinte anos depois da primeira pesquisa quantitativa sobre o tema, o cenário não é distinto (Tabela 6).

TABELA 6 - Avaliação positiva (soma das respostas concorda totalmente e em parte) feita pelos membros do Ministério Público (União e Estados) em oito assertivas

\begin{tabular}{|c|c|}
\hline Assertiva & $\begin{array}{c}\text { Percentual } \\
(\%)\end{array}$ \\
\hline $\begin{array}{l}\text { Cabe obrigatoriamente ao Ministério Público exigir da Administração Pública } \\
\text { que assegure os direitos previsto nas Constituições } \\
\text { (Federal e Estadual) e nas leis }\end{array}$ & 97,2 \\
\hline $\begin{array}{l}\text { O Ministério Público desempenha papel de promoção da cidadania } \\
\text { e conscientização da sociedade brasileira }\end{array}$ & 96,3 \\
\hline $\begin{array}{l}\text { O Ministério Público é o canal de vocalização de demandas sociais } \\
\text { com vistas a alargar o acesso à solução de conflitos coletivos }\end{array}$ & 94,7 \\
\hline A sociedade desconhece as atribuições constitucionais do Ministério Público & 89,2 \\
\hline $\begin{array}{l}\text { O Ministério Público assegura contraditório e a possibilidade } \\
\text { de manifestação dos investigados em algum momento do procedimento }\end{array}$ & 80,6 \\
\hline O Ministério Público é socialmente engajado & 75,7 \\
\hline $\begin{array}{l}\text { O Ministério Público ouve todos os envolvidos em uma questão } \\
\text { antes de se manifestar }\end{array}$ & 67,8 \\
\hline $\begin{array}{l}\text { No Ministério Público há uma pressão para que o compromisso } \\
\text { com a justiça social prepondere sobre a estrita aplicação das leis }\end{array}$ & 54,5 \\
\hline
\end{tabular}


A quase totalidade dos entrevistados concorda, no todo ou em parte, com três afirmações que, apesar de diversas, expressam os principais slogans do MP após a Constituinte: a) "cabe obrigatoriamente ao Ministério Público exigir da Administração Pública que assegure os direitos previstos nas Constituições (Federal e Estadual) e nas leis" (97,2\%) e b) "o Ministério Público desempenha papel de promoção da cidadania e conscientização da sociedade brasileira" (96,3\%). Ambas dizem respeito ao papel da instituição como guardiã dos ideais republicanos, o que seria viabilizado pela atuação de seus membros, que devem exigir das repartições públicas o estrito cumprimento do dever legal, assegurar que todos os indivíduos tenham consciência de seus direitos e deveres, além de resguardar qualquer sujeito de excessos praticados por outrem, empresa ou até mesmo pelo poder público.

Daí vem o endosso à ideia de que c) "o Ministério Público é o canal de vocalização de demandas sociais com vistas a alargar o acesso à solução de conflitos coletivos" (89,2\%). Para vários dos entrevistados, a "clínica geral” (Silva, 2001) que qualifica o trabalho no interior do Brasil é exemplo irrefutável de que a instituição é indispensável à administração da justiça, posto que encaminha os sujeitos vulneráveis para atendimentos e órgãos públicos.

A afirmação "o Ministério Público é socialmente engajado" contou com a aprovação total ou parcial de $75,7 \%$ dos entrevistados. A possibilidade de a instituição atuar na defesa dos direitos difusos, coletivos e individuais homogêneos inaugura, formalmente, a judicialização de conflitos políticos (Arantes, 1999: 88). Considerando que essa é reconhecida como a principal mudança institucional dada pela constituinte (Cardia et al., 1998), o percentual confirma que os atuais membros do MP se percebem, simultaneamente, como operadores da justiça e atores políticos. Todavia, a ação política parece ter um limite claro para os entrevistados.

Ao contrário do idealizado na constituinte, os membros do MP reconhecem que sua atuação deve sempre se basear no arcabouço jurídico existente, ainda que esse venha a ferir determinados direitos. Por isso, a frase com maior percentual de discordância foi "no Ministério Público há uma pressão para que o compromisso com a justiça social prepondere sobre a estrita aplicação das leis" ( $54,5 \%$ concordam total ou parcialmente). Agir de acordo com a justiça social é atuar com vistas a corrigir injustiças provocadas por políticas públicas, decisões dos entes federados e, ainda, dispositivos legais. É uma ação mais especializada, operacionalizada a partir de mecanismos extrajudiciais, como tem ocorrido nas áreas da saúde (Asensi, 2010) e da educação (Marques et al., 2000).

O compromisso com a justiça social significa acionar os princípios previstos no Art. $1^{\circ}$. da Carta Magna, em detrimento de se ater a qualquer outra normativa 
existente no ordenamento jurídico. É uma tentativa realizar "os ideais de justiça estabelecidos na Constituição, livrando-se de dogmas conservadores que só interessam à manutenção da injustiça social" (Marques et al., 2000: 279). Para tanto, o membro do MP deve ter a consciência de que é a sua ação socialmente engajada que será capaz de modificar "o mundo fático além do jurídico" (ibidem). Talvez o rechaço a essa assertiva se deva à função do MP como "fiscal da lei", o que significa "acompanhar a aplicação da lei pelo juiz em casos concretos envolvendo direitos individuais considerados indisponíveis" não como um dos envolvidos no processo, mas sim como uma terceira figura, "representando o Estado e sua função pública de zelar por direitos indisponíveis e interesses de indivíduos classificados juridicamente como incapazes" (Arantes, 1999: 84).

Nesta senda, tentamos mapear quais as temáticas que têm demandado maior esforço institucional. Para tanto, os entrevistados deveriam avaliar a atuação de sua instituição (MPE ou MPU) em 29 áreas - que representariam as novas atribuições concedidas ao MP pela CR/1988 -, utilizando conceitos que variavam entre péssimo e ótimo. Considerando os percentuais que configuram uma avaliação positiva, isto é, atuação ótima ou boa, constata-se que a promoção da ação penal pública incondicionada, ${ }^{13}$ aquela em que o processo penal pode ser iniciado independentemente da vontade da vítima, foi a que recebeu melhor avaliação, com $80 \%$ de ótima ou boa (Tabela 7 ).

TABELA 7 - Avaliação positiva (somatório de boa e ótima) da atuação da instituição em que o entrevistado trabalha

Áreas de atuação do Ministério Público

Percentual

$(\%)$

Promoção da ação penal pública

80

Oferecimento de representação ante a prática de ato infracional

76

Fiscalização do processo eleitoral

74

Atendimento ao público

73

Proteção e garantia dos direitos das crianças e adolescentes na seara protetiva 72

Proteção do meio ambiente 68

cont.

\footnotetext{
13 No caso brasileiro, os promotores e os procuradores que atuam na área penal não possuem discricionariedade para decidir se uma ação criminal deve ou não ser levada ao Judiciário. Essa situação obriga o membro do MP “a levar todos os casos ao Poder Judiciário, independentemente da gravidade do mesmo, é o chamado princípio da legalidade, modelo não utilizado em todos os países" (Kerche, 2007: 272-273).
} 
cont.

Áreas de atuação do Ministério Público

$(\%)$

Fiscalização do cumprimento da lei (custos legis) 68

Defesa do consumidor $\quad 66$

Combate à improbidade $\quad 64$

Promoção de ação socioeducativa (promoção de medidas protetivas) 63

Condução de investigação criminal

Defesa da Saúde Pública $\quad 59$

Defesa dos Portadores de Necessidades Especiais $\quad 58$

Defesa da Educação

Fiscalização de estabelecimento de acolhimento institucional de crianças e adolescentes 53

Promoção da ação penal originária $\quad 50$

Fiscalização dos estabelecimentos que abrigam idosos, incapazes ou pessoas com deficiência

Fiscalização de estabelecimentos de privação de liberdade

Controle da constitucionalidade de leis e atos normativos estaduais

e municipais em face da Constituição Estadual

Fiscalização de unidades de cumprimento de medidas socioeducativas

Fiscalização da execução penal

Controle da constitucionalidade de leis e atos normativos federais em face da Constituição Federal

Desenvolvimento de planos estratégicos e medidas concretas para assegurar o respeito aos poderes

Representação dos interesses da sociedade no âmbito de conselhos sociais/ conferências municipal

Defesa dos direitos dos povos tradicionais (indígenas, quilombolas, ciganos, outros)

Fiscalização das Fundações de Direito Privado

Fiscalização das Casas Abrigo (criadas no âmbito da Lei Maria da Penha)

Fiscalização dos conselhos sociais/conselhos de políticas públicas 
Outras áreas que receberam uma avaliação positiva com percentual de ótimo e bom superior a $70 \%$ foram: oferecimento de representação à prática de ato infracional, que é a imputação a um adolescente de uma conduta que, quando praticada por um adulto, seria considerada criminosa; fiscalização do processo eleitoral, função que tem ganhado proeminência após o último pleito eleitoral (2014), quando a chapa da presidente eleita Dilma Rousseff passou a ser questionada pelo MP em razão dos desvios de recurso; ${ }^{14}$ atendimento ao público, atividade indispensável para o mapeamento das demandas da população; e proteção e garantia dos direitos das crianças e dos adolescentes na seara protetiva, atribuição recebida com a entrada em vigor do Estatuto da Criança e do Adolescente (ECA, 1990).

Com avaliação acima de $60 \%$ estão seis temáticas: meio ambiente, atribuição decorrente da Lei 6.938/1981, que garante o direito de todos a um meio ambiente natural sustentável; custos legis (68\% de ótima e boa), que levaria à bandeira de que o membro do MP é alguém que promove a justiça por garantir que as leis existentes serão cumpridas; defesa do consumidor (66\%), decorrente da Lei 7.437/1985, que admite a possibilidade de ação civil pública para práticas que violem relações livres e justas de consumo; combate à improbidade (64\%), que tem ganhado visibilidade nas investigações e procedimentos da Operação Lava Jato $;^{15}$ promoção de ação socioeducativa $(63 \%)$, que visa garantir que jovens em situação de vulnerabilidade social não sejam vítimas ou autores de crimes; e, por fim, condução da investigação policial (61\%), que ocorre quando os membros do MP atuam em conjunto com as polícias civis e federal para a produção de provas que permitam a incriminação (ou não) de determinados indivíduos, o que também tem sido recorrente na Operação Lava Jato.

As demais 13 áreas receberam uma avaliação positiva entre $60 \%$ e $30 \%$, indicando que o entrevistado não as percebia como searas prioritárias ou temáticas relegadas a segundo plano. Vale ressaltar que o controle externo da atividade policial foi visto como atribuição precariamente atendida pelo MP: somente $21 \%$ fizeram uma avaliação positiva, sendo que $47,1 \%$ a classificaram como ruim ou péssima. Na pesquisa pioneira sobre o MP, Sadek (1997) encontrou o mesmo resultado, indicando que este parece ser o calcanhar de aquiles da instituição.

\footnotetext{
${ }_{14}$ Nesse sentido, ver: http://agenciabrasil.ebc.com.br/politica/noticia/2016-12/tse-deixa-julgamento-sobre-chapa-dilma-temer-para-2017. Consultado a 09.12.2016.

15 Trata-se de força tarefa entre a Polícia Federal, o Ministério Público Federal e a Justiça Federal para a investigação de casos de corrupção envolvendo políticos de relevância no cenário nacional. Desde o seu início, milhares de Reais desviados dos cofres públicos retornaram ao país. Para um maior conhecimento de como o próprio Ministério Público apresenta essa modalidade de ação, ver http://lavajato.mpf.mp.br/entenda-o-caso (consultado a 09.12.2016).
} 
Se a CR/1988 significou para o MP "uma espécie de certidão de (re)nascimento institucional, suficiente para habilitá-lo a ultrapassar suas funções tradicionais e reforçar sua responsabilidade pela defesa dos direitos coletivos e sociais" (Arantes, 1999: 87), na visão dos entrevistados nem todas as atividades são executadas a contento, sendo que as tradicionalmente associadas à defesa do Estado preponderam em relação àquelas qualificadas como defesa da sociedade. Para entender quais são as prioridades institucionais, pedimos aos entrevistados para apontá-las a partir de uma lista de 24 itens (Tabela 8).

A categoria mais mencionada pelos respondentes foi o combate à corrupção $(67 \%)$, o que pode ser decorrente do próprio momento político vivido pelo país, com a visibilidade da Operação Lava Jato, que segundo o site do MPF é "a maior investigação de corrupção e lavagem de dinheiro que o Brasil já teve". ${ }^{16} \mathrm{O}$ MP tem se destacado na revelação e acusação de indivíduos e empresas que operaram esquemas de desvios de verbas públicas, sendo reconhecido como tal pela população. Os entrevistados parecem endossar, ao seu turno, essa percepção social, enumerando a corrupção como a primeira da lista de áreas prioritárias.

\section{TABELA 8 - Áreas prioritárias de atuação no Ministério Público em que o entrevistado trabalha}

\begin{tabular}{lc}
\hline Área & $\begin{array}{c}\text { Prioridade } \\
\text { para \% }\end{array}$ \\
\hline Combate à corrupção (defesa do patrimônio público, improbidade administrativa) & 62 \\
\hline Investigação criminal & 49 \\
\hline Defesa dos direitos da criança e adolescente (em geral) & 47 \\
\hline Meio ambiente & 45 \\
\hline Serviços de relevância pública (saúde, educação, etc.) & 40 \\
\hline Júri & 29 \\
\hline Fiscal da lei (custos legis) & 24 \\
\hline Defesa dos direitos de crianças e adolescentes em situação de risco & 20 \\
\hline Defesa dos direitos de mulheres vítimas de violência doméstica/familiar & 19 \\
\hline Defesa do consumidor e ordem econômica & 18 \\
\hline Execução penal (cumprimento de penas e medidas alternativas) & 15 \\
\hline Eleitoral & 15 \\
\hline
\end{tabular}

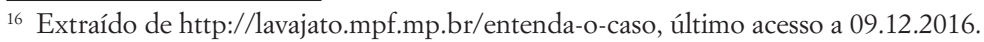


cont.

\begin{tabular}{lc}
\hline Área & $\begin{array}{c}\text { Prioridade } \\
\text { para \% }\end{array}$ \\
\hline Proteção das relações de trabalho & 14 \\
\hline Controle externo da atividade policial & 12 \\
\hline Defesa dos direitos das pessoas idosas & 9 \\
\hline Outra (especificar) & 9 \\
\hline Defesa dos direitos das pessoas com deficiência & 7 \\
\hline Patrimônio histórico e cultural & 6 \\
\hline Defesa dos direitos das minorias étnicas (indígenas, quilombolas e outros povos & 4 \\
\hline tradicionais) & 4 \\
\hline Defesa dos direitos de gênero (LGBTs, transexuais, homossexuais, etc.) & 2 \\
\hline Política fundiária e reforma agrária & 1 \\
\hline Justiça Militar &
\end{tabular}

Fonte: Ministério Público: guardião da democracia? (CESeC, 2016).

A segunda temática com maior quantidade de menções foi a investigação criminal $(49 \%)$, que aparece com $13 \%$ a menos que a primeira colocada. Considerando que a retirada dessa atribuição era a mudança proposta pela PEC 37, além de a atividade de acusação do MP se basear nas provas coletadas ao longo da investigação, era de se esperar que um número maior de entrevistados a mencionasse como prioridade.

Entre as temáticas pouco reconhecidas estão a defesa dos direitos de minorias históricas (como remanescentes de quilombo e indígenas), das novas minorias (como LGBT), além da Justiça Militar. Desde a Lei Bicudo (Lei 9.299/1999), confirmada pela a Emenda Constitucional n. ${ }^{\circ}$ 45/2004, compete ao Tribunal do Júri processar os homicídio dolosos (intencionais) praticados por policiais militares, no exercício da função, contra vítimas civis. A Justiça Militar, por sua vez, deve processar e julgar as mortes culposas, isto é, os óbitos resultantes de imprudência, negligência ou imperícia na prática do policiamento ostensivo pela Polícia Militar. Assim, atuar na Justiça Militar significa diferenciar quais são as mortes dolosas das culposas, para adequado encaminhamento. Em um país que registra seis mortes pela PM diariamente (FBSP, 2016), essa área deveria ser uma das maiores prioridades da instituição. Ao não garantir que as mortes praticadas pela PM sejam adequadamente punidas, os membros do MP legitimam a existência de uma justiça extralegal, que impõe a pena a morte (Zaccone, 2015). Quando os entrevistados colocam essa atribuição na última posição do ranking 
de prioridades institucionais, eles ratificam a dificuldade em assumir o controle externo da atividade policial como uma tarefa inerente às suas atribuições constitucionais.

No campo "outros", os entrevistados puderam precisar o que eles qualificavam como áreas prioritárias, para além das listadas. A grande maioria reafirmou que o "combate à criminalidade" era a grande missão do MP. Outros apresentaram várias críticas à postura que a instituição adota, destacando que sua prioridade é "obter espaço na mídia, não entrar em choque com o Governo Estadual” (Q.80) ou são "os interesses privados" (Q.822). Não restam dúvidas de que, apesar de todas as mudanças decorrentes da CR/1988, na visão de seus próprios membros, uma das principais funções do Ministério Público é a área penal.

\section{Os membros do MP são promotores da ação penal ou verdadeiros agentes garantidores de uma sociedade mais justa?}

Em seu trabalho sobre as elites jurídicas, Almeida (2014: 80) afirma que a única maneira de se compreender a estruturação e funcionamento de um campo (no sentido bourdieusiano do termo) dentro do sistema de justiça é a partir da investigação sobre a forma de combinação de categorias como a origem dos membros, o exercício e a distribuição de poder dentro do interior da agência vis-à-vis "fenômenos de origem social e simbólica (mais especificamente, aqueles relacionados às divisões de classe, gênero e prestígio), bem como aqueles decorrentes das funções e divisões político-institucionais".

Para combinar essa miríade de características apontadas por Almeida (2014) como relevantes para o entendimento dos processos de hierarquização ou mesmo autonomização dentro de campos jurídicos, procedemos a uma análise de cluster do tipo K-Médias (Hartigan e Wong, 1979), que consiste numa operação matemática em que os algoritmos dividem os participantes da pesquisa em agrupamentos, a partir de determinados critérios. Trata-se, assim, do emprego de uma técnica estatística que viabiliza a criação de um conjunto em que os componentes são mais semelhantes, segundo determinados critérios, do que os pertencentes a outros conjuntos (Vinhas et al., 2002).

O cluster K-médias é o tipo de algoritmo recomendado para a classificação não supervisionada, isto é, quando a alocação do indivíduo em um grupo em detrimento dos demais é dada por algum critério de convergência (Hartigan e Wong, 1979). Para a criação dos clusters K-médias a partir dos dados da pesquisa, o cálculo dos algoritmos levou em consideração a área de atuação, a percepção da área penal como prioridade do MP e o lugar de trabalho (capital ou interior).

A área de atuação do membro do MP é importante para separar aqueles que atuam na clínica geral, agindo em todas as áreas; daqueles que exercem 
a profissão de forma muito especializada (Tabela 9). Do total de entrevistados, somente $9,4 \%$ podiam ser encaixados no primeiro grupo. A tendência é a divisão dos promotores e procuradores em dois grupos principais: aqueles que não trabalham em quaisquer das três áreas mencionadas $(26,3 \%)$, se concentrando no oferecimento da denúncia no processo penal, e aqueles que atuam na área de direitos difusos, coletivos e individuais homogêneos (38,8\%).

TABELA 9 - Áreas de atuação especializadas dos promotores e procuradores de justiça

\begin{tabular}{lrc}
\hline Áreas de atuação & Absoluto & Percentual \\
\hline Somente direitos difusos, coletivos e individuais homogêneos & 349 & 38,8 \\
\hline Somente controle externo da polícia & 65 & 7,2 \\
\hline Somente supervisão da pena privativa de liberdade & 36 & 4,0 \\
\hline Direitos difusos e controle externo da polícia & 110 & 12,3 \\
\hline Direitos difusos e supervisão da pena privativa de liberdade & 18 & 2,0 \\
\hline Direitos difusos, controle externo da polícia e supervisão da prisão & 85 & 9,4 \\
\hline Não atua em quaisquer das três áreas mencionadas & 236 & 26,3 \\
\hline Total & 899 & 100,0 \\
\hline
\end{tabular}

Fonte: Ministério Público: guardião da democracia? (CESeC, 2016).

Os direitos difusos, coletivos e individuais homogêneos foram introduzidos na administração da justiça com a CR/1988 e abraçados por um quantitativo elevado de entrevistados, seja de forma exclusiva $(38,8 \%)$ ou combinada com alguma outra seara $(23,7 \%)$. O controle externo da atividade policial e a supervisão da execução da pena privativa de liberdade, por sua vez, são temáticas claramente relegadas a segundo plano. Esses temas eram vistos, na promulgação da nova Carta, como as searas em que o MP dificilmente conseguiria ter uma atuação mais especializada (Sadek, 1997). Aparentemente, o prognóstico daquela época se confirmou, o que pode ser explicado pela prevalência da tradicional função de acusador no processo penal, atividade reconhecida como prioridade máxima por $48,6 \%$ dos entrevistados.

Outra variável escolhida para compor o cluster foi o lugar de trabalho - se capital e região metropolitana ou se interior. Isso porque a forma de organização da carreira privilegia a capital (e região metropolitana) como centro do poder, o que contribui para que a experiência do interior seja o único momento em que o indivíduo se envolve na "clínica geral" (Silva, 2001), posto que ele não pode escolher claramente quem 
beneficiar com a sua ação. Então, quando o profissional alcança um determinado nível na carreira, ele pode ser transferido para a capital, atuando de uma forma mais especializada e, por conseguinte, muitas vezes distante da população. Quando no início da carreira no interior, o profissional não pode se furtar ao exercício das atividades de defesa dos direitos difusos, coletivos e individuais homogêneos, e ainda controle externo da polícia e supervisão da pena privativa de liberdade, mesmo que não veja o menor sentido para essas atribuições.

$\mathrm{Na}$ capital, uma parcela substantiva de membros do MP não atua em quaisquer das temáticas mencionadas $(39,8 \%)$, ou atua tão somente na seara de direitos difusos, coletivos e individuais homogêneos (42\%). No interior, os profissionais combinam duas ou três das temáticas (35\%), o que explica o baixo quantitativo que não atua em quaisquer delas $(12,7 \%)$. Como este resultado foi estatisticamente significativo (Tabela 10), conclui-se que a atuação (ou não) nas temáticas pesquisadas decorre do momento da carreira em que o profissional se encontra: se no início, na "clínica geral" do interior, ou no fim, quando o exercício da profissão é especializado nas áreas metropolitanas.

TABELA 10 - Áreas de atuação especializadas dos promotores e procuradores de justiça, por comarca de lotação

\begin{tabular}{|c|c|c|c|c|c|}
\hline & & & \multicolumn{2}{|c|}{$\begin{array}{l}\text { Em termos geográficos, } \\
\text { o(a) Sr.(a) atua: }\end{array}$} & \multirow[b]{2}{*}{ Total } \\
\hline & & & $\begin{array}{c}\mathrm{Na} \text { capital } \\
\text { (e respectivas regiões } \\
\text { metropolitanas) }\end{array}$ & $\begin{array}{c}\text { No } \\
\text { interior }\end{array}$ & \\
\hline \multirow[t]{10}{*}{ Áreas } & \multirow{2}{*}{ Somente direitos difusos } & $\mathrm{N}$ & 189 & 160 & 349 \\
\hline & & $\%$ & 42,0 & 35,6 & 38,8 \\
\hline & \multirow{2}{*}{$\begin{array}{l}\text { Somente controle externo } \\
\text { da polícia }\end{array}$} & $\mathrm{N}$ & 28 & 37 & 65 \\
\hline & & $\%$ & 6,2 & 8,2 & 7,2 \\
\hline & \multirow{2}{*}{$\begin{array}{l}\text { Somente supervisão da pena } \\
\text { privativa de liberdade }\end{array}$} & $\mathrm{N}$ & 16 & 20 & 36 \\
\hline & & $\%$ & 3,6 & 4,4 & 4,0 \\
\hline & \multirow{2}{*}{$\begin{array}{l}\text { Direitos difusos e controle } \\
\text { externo da polícia }\end{array}$} & $\mathrm{N}$ & 28 & 83 & 111 \\
\hline & & $\%$ & 6,2 & 18,4 & 12,3 \\
\hline & \multirow{2}{*}{$\begin{array}{l}\text { Direitos difusos e supervisão } \\
\text { da pena privativa de liberdade }\end{array}$} & $\mathrm{N}$ & 6 & 12 & 18 \\
\hline & & $\%$ & 1,3 & 2,7 & 2,0 \\
\hline
\end{tabular}




\begin{tabular}{|c|c|c|c|c|c|}
\hline & & & \multicolumn{2}{|c|}{$\begin{array}{l}\text { Em termos geográficos, } \\
\text { o(a) Sr.(a) atua: }\end{array}$} & \multirow[b]{2}{*}{ Total } \\
\hline & & & $\begin{array}{c}\text { Na capital } \\
\text { (e respectivas regiões } \\
\text { metropolitanas) }\end{array}$ & $\begin{array}{l}\text { No } \\
\text { interior }\end{array}$ & \\
\hline & \multirow{2}{*}{$\begin{array}{l}\text { Direitos difusos, controle externo } \\
\text { da polícia e supervisão da prisão }\end{array}$} & $\mathrm{N}$ & 4 & 81 & 85 \\
\hline & & $\%$ & 0,9 & 18,0 & 9,4 \\
\hline & \multirow{2}{*}{$\begin{array}{l}\text { Não atua em quaisquer das três } \\
\text { áreas mencionadas }\end{array}$} & $N$ & 179 & 57 & 236 \\
\hline & & $\%$ & 39,8 & 12,7 & 26,2 \\
\hline \multirow[t]{2}{*}{ Total } & & $N$ & 450 & 450 & 900 \\
\hline & & $\%$ & 100,0 & 100,0 & 100,0 \\
\hline
\end{tabular}

Qui-quadrado: 166,17 (0,000).

Fonte: Ministério Público: guardião da democracia? (CESeC, 2016).

O cluster K-médias criado com as três variáveis (lugar de atuação, área de atuação e prioridade da instituição) demonstrou que essas dimensões se encontram associadas de forma estatisticamente significativa. Segundo o teste ANOVA, a área de atuação parece ser a variável com maior peso nesta equação (Tabela 11), seguida pelo lugar de atuação e a percepção da área penal como prioridade da instituição.

TABELA 11 - Teste ANOVA para variáveis inseridas no cluster K-médias

\begin{tabular}{|c|c|c|c|c|c|c|}
\hline \multirow[b]{2}{*}{ Variáveis } & \multicolumn{2}{|c|}{ Cluster } & \multicolumn{2}{|c|}{ Erro } & \multirow{2}{*}{$F$} & \multirow{2}{*}{ Sig. } \\
\hline & $\begin{array}{l}\text { Quadrado } \\
\text { Médio }\end{array}$ & gl & $\begin{array}{l}\text { Quadrado } \\
\text { Médio }\end{array}$ & Gl & & \\
\hline $\begin{array}{l}\text { Em termos geográficos, } \\
\text { o(a) Sr.(a) atua: na capital } \\
\text { (RM) ou no interior? }\end{array}$ & 1,774 & 1 & 0,249 & 896 & 7,136 & ,008 \\
\hline $\begin{array}{l}\text { O (A) Sr. (a) considera que } \\
\text { o Ministério Público em } \\
\text { que trabalha tem como } \\
\text { prioridade a área penal? }\end{array}$ & 1,528 & 1 & 0,249 & 896 & 6,143 &, 013 \\
\hline Áreas de atuação & 6668,795 & 1 & 1,171 & 896 & 5697,363 & 0,000 \\
\hline
\end{tabular}


O cluster K-médias criou uma nova variável, que agrupou os promotores e procuradores em dois grupos distintos, com diferença estatisticamente significativa. ${ }^{17}$ De um lado, estão os profissionais que atuam na capital, que privilegiam temas específicos de atuação como a área penal ou a proteção e garantia de direitos difusos, coletivos e individuais homogêneos, entendendo que o papel do MP é a defesa do Estado. De outro, estão os profissionais que atuam no interior e exercem todas as funções outorgadas pela CR/1988, entendendo que o papel do Ministério Público é a defesa da sociedade.

Denominaremos o primeiro grupo de promotores ou procuradores de gabinete $(87,8 \%)$ e o segundo de promotores ou procuradores de fato $(12,2 \%)$. Essa dicotomia - promotores de gabinete versus de fato - foi elaborada por Silva (2001) para a compreensão dos diferentes cursos de ação dos promotores de São Paulo na seara de defesa dos direitos da cidadania. Nós a empregamos com outra conotação, restringindo as competências do gabinete às funções tradicionais do MP e ampliando as de fato, além de incluirmos os procuradores da União na análise.

Entendemos que o promotor ou procurador de gabinete é aquele que trabalha nas capitais e regiões metropolitanas de forma bastante especializada, considerando que a sua principal responsabilidade é dar conta dos processos, promovendo a denúncia e participando de audiências. O promotor ou procurador de fato, por sua vez, se engaja em atividades indispensáveis à administração da justiça para além da seara criminal, procurando reparar uma série de injustiças cometidas por indivíduos, empresas ou órgãos públicos, para garantia da justiça social.

São promotores ou procuradores de fato aqueles que se engajam ativamente em atribuições relacionadas à construção da cidadania. Os promotores e procuradores de gabinete são críticos a essa postura, preferindo a lentidão do judiciário a um trabalho mais intenso como ator político. Como lidam apenas com papéis, não conseguem entender o modo como o desenho organizacional não favorece aqueles que não podem esperar tantos anos pela prestação de um serviço público essencial. A distância das emoções que o papel promove impede que o membro do MP entenda o quanto a sua ação é indispensável para a sobrevivência de determinados grupos.

Os dois grupos gerados pela análise de cluster evidenciam que, quase trinta anos após a promulgação da CR/1988, o Ministério Público não absorveu plenamente as competências que lhe foram outorgadas e, por isso, continua agindo de acordo com os parâmetros de sua velha constituição. Ainda que uma boa parte dos membros do MP possua mais de uma área

$\overline{17}$ Teste T de médias igual a $102,82(0,000)$. 
de competência, a sua qualificação é de promotor de gabinete, já que seguem priorizando a área criminal ou uma atividade especializada na capital. Em que pese o envolvimento de alguns na defesa de direitos difusos, coletivos e individuais homogêneos, as pessoas mortas pela polícia e encarceradas continuam não merecendo a atenção dos membros do MP. Em suma, os membros do MP são promotores da ação penal, em detrimento de verdadeiros agentes garantidores de uma sociedade mais justa.

\section{Considerações finais}

A sociologia jurídica brasileira tem se utilizado de diversos conceitos da sociologia das elites e das profissões para entender o processo de funcionamento das instituições que compõem o sistema de justiça, especialmente com a emergência da nova ordem constitucional (Sadek, 2002). No entanto, essa área ainda tem poucos estudos que, a partir do conceito de campo de Bourdieu (1998), sejam capazes de compreender as origens, a organização, a distribuição de atividades e a centralização do próprio poder dentro de organizações como o Judiciário, o Ministério Público e a Defensoria Pública (Almeida, 2014).

Procurando suprimir essa lacuna, desvelamos como o campo do Ministério Público se caracteriza na atualidade. Trata-se de uma instituição que remonta ao Brasil Imperial e assumiu uma miríade de funções na ordem constitucional inaugurada a partir de 1988. A partir dos dados coletados com uma pesquisa quantitativa, revelamos como os membros do MP têm dificuldade em se posicionar de forma mais ativa diante da tarefa de construção de uma sociedade mais democrática.

Compreenderemos melhor esse resultado se entendermos o Ministério Público enquanto um campo estruturado a partir de um grupo social e político que se autogoverna. Constatamos que o MP se constitui em uma carreira masculina exercida em boa medida por filhos, sobrinhos e netos de bacharéis e que conta com poucos membros de cor. Em parte, as restrições impostas pelo concurso, organizado por aqueles que já integram o campo há várias gerações, faz com que o recrutamento de novos membros esteja fechado em uma parcela bem específica da população brasileira. Ao bloquear o ingresso de outras camadas sociais, veda-se a transformação de ideias no próprio campo, o que impede a renovação de suas práticas.

Como instituição do campo do sistema de justiça, o MP tem garantido a sua legitimidade atuando em áreas congêneres à acusação no processo penal, como é o caso do combate à corrupção, a responsabilização penal de empresas pela destruição do meio ambiente, o oferecimento de representação contra adolescentes que praticaram ato infracional e assim sucessivamente. É, portanto, uma elite que está mais preocupada em construir a sua credibilidade perante 
a opinião pública do que com a transformação da sociedade e, por isso, seus membros não se ocupam em priorizar o controle externo de uma das polícias mais letais do mundo, a supervisão da quarta maior população prisional do planeta e a defesa dos direitos de segmentos sociais tradicionalmente excluídos da política pública nacional, como é o caso das minorias étnicas e sexuais.

Por outro lado, a quantidade de funções concentradas no MP com a CR/1988 fez surgir certa dualidade em suas atribuições: ora essa agência deve atuar na defesa do Estado (como fiscal da lei e titular da ação penal), ora deve atuar na defesa da sociedade (contra o Estado quando esse é o violador de direitos). Como dificilmente essas duas atribuições podem ser conjugadas em um único sujeito, os promotores ou procuradores parecem se posicionar de um lado bem específico do espectro: a defesa do Estado, pela via da ação penal.

Neste cenário, o campo do Ministério Público pode ser entendido como uma estrutura que privilegia a ação de gabinete, prioritariamente com pouca ênfase na melhoria da qualidade de vida da população hipossuficiente, em detrimento de uma ação de fato na busca de mais justiça social, quando as leis existentes são contrárias a essa ideia. Assim, o MP se conforma em um excelente exemplo de velha instituição com novas funções: os seus membros ainda são os mesmos do ponto de vista da classe de recrutamento e, por isso, as ações por eles realizadas não são substancialmente distintas das que caracterizavam o órgão antes da mudança constitucional.

\section{Referências bibliográficas}

Almeida, Frederico de (2014), "As elites da justiça: instituições, profissões e poder na política da justiça brasileira”, Revista de Sociologia e Política, 22(52), 77-95.

Arantes, Rogério Bastos (1999), "Direito e política: o Ministério Público e a defesa dos direitos coletivos", Revista Brasileira de Ciências Sociais, 14(39), 83-102.

Asensi, Felipe Dutra (2010), Indo além da judicialização: o Ministério Público e a saúde no Brasil. Rio de Janeiro: Fundação Getúlio Vargas.

Azevedo, Rodrigo Ghiringhelli de (2010), Perfil socioprofissional e concepções de política criminal do Ministério Público Federal. Brasília: Escola Superior do Ministério Público da União.

Bourdieu, Pierre (1998), "A força do direito: elementos para uma sociologia do campo jurídico”, O poder simbólico. Rio de Janeiro: Bertrand Brasil.

Cardia, Nancy; Adorno, Sérgio; Pinheiro, Paulo Sérgio (1998), Pesquisa Direitos Humanos e Democracia: Proposta de Intervenção na Formação de Profissionais do Judiciário, Ministério Público e da Polícia no Estado de São Paulo, Brasil. São Paulo: NEV/USP e CEE. 
Castilho, Ela Wiecko Volkmer de; Sadek, Maria Tereza (1998), O Ministério Público Federal e a administração da justiça no Brasil. Rio de Janeiro: Centro Edelstein de Pesquisa Social.

Coelho, Edmundo Campos (1999), As profissões imperiais: advocacia, medicina e engenharia no Rio de Janeiro, 1822-1930. Rio de Janeiro: Editora Record.

Comin, Álvaro A.; Barbosa, Rogério Jerônimo (2011), "Trabalhar para estudar: sobre a pertinência da noção de transição escola-trabalho no Brasil", Novos estudos CEBRAP, 91, 75-95.

Cunha, Luciana Gross; Bueno, Rodrigo de Losso da Silveira; Oliveira, Fabiana Luci de; Sampaio, Joelson de Oliveira; Ramos, Luciana de Oliveira; Macedo, Gabriel Hideo Sakai de (2014), Relatório ICJBrasil - 2. ${ }^{\circ}$ e 3. ${ }^{\circ}$ trimestres/2014. São Paulo: Escola de Direito de São Paulo da Fundação Getulio Vargas.

FBSP - Fórum Brasileiro de Segurança Pública (2016), 10. ․ Anuário do Fórum Brasileiro de Segurança Pública. São Paulo: Fórum Brasileiro de Segurança Pública.

Gershman, Bennett L. (1992), “The New Prosecutors”, University of Pittsburgh Law Review, 53, p. 393.

Hartigan, John A.; Wong, Manchek A. (1979), "Algorithm AS 136: A K-means Clustering Algorithm”, Journal of the Royal Statistical Society. Series C (Applied Statistics), 28(1), 100-108.

Kakar, Suman (2002), “Gender and Police Officers' Perceptions of their Job Performance: An Analysis of the Relationship between Gender and Perceptions of Job Performance”, Criminal Justice Policy Review, 13(3), 238-256.

Kerche, Fábio (2007), "Autonomia e discricionariedade do Ministério Público no Brasil”, DADOS - Revista de Ciências Sociais, 50(2), 259-279.

Marques, Antonio Emílio Sendim; Brancher, Leoberto Narciso; Konzen, Afonso Armando; Vieira, Alessandra; Sari, Marisa; Rodrigues, Maristela Marques; Cury, Munir (2000), Pela justiça na educação. Brasília: MEC/FUNDESCOLA.

Paula, Christiane Jalles (2010), "Trajetória e auto-imagem do Ministério Público do Rio de Janeiro", Revista Estudos Políticos, 1.

Sadek, Maria Tereza (org.) (1997), O Ministério Público e a justiça no Brasil. São Paulo: IDESP/Editora Sumaré.

Sadek, Maria Tereza (2002), "Estudos sobre o sistema de justiça”, in Sergio Miceli (org.), O que ler na ciência social brasileira, vol. 4. São Paulo: Editora Sumaré 233-265.

Silva, Cátia Aida (2001), Promotores de Justiça e novas formas de atuação em defesa de interesses sociais e coletivos. São Paulo: Associação Nacional de Pós-Graduação e Pesquisa em Ciências Sociais.

Sinhoretto, Jacqueline (2011), A justiça perto do povo: reforma e gestão de conflitos. São Paulo: Alameda.

Vargas, Hustana Maria (2010), "Sem perder a majestade: 'profissões imperiais' no Brasil”, Estudos de Sociologia, 15(28). 
Vianna, Luiz Werneck; Carvalho, Maria Alice Rezende de; Melo, Manuel Palacios Cunha; Burgos, Marcelo Baumann (1997), Corpo e alma da magistratura brasileira. Rio de Janeiro: Editora Revan.

Vinhas, Lubia; Queiroz, Gilberto Ribeiro; Ferreira, Karine Reis; Câmara, Gilberto; Paiva, João Argemiro (2002), "Programação genérica aplicada a algoritmos geográficos", Anais do IV Simpósio Brasileiro de GeoInformática, vol. 1, 117-122.

Volpe, Ana Paula Sampaio; Goes, Fernanda Lira; Lobo, Marta Santos da Silva Holanda; Silva, Tatiana Dias (2012), "Igualdade racial”, Políticas sociais: acompanbamento e análise. Brasília: IPEA, capítulo 11.

Weber, Max (1999), Economia e sociedade, vol. 2. Brasília: Editora UNB.

Zaccone, Orlando (2015), Indignos de vida: a forma jurídica da politica de extermínio de inimigos na cidade do Rio de Janeiro. Rio de Janeiro: Editora Revan.

Artigo recebido a 06.05.2016

Aprovado para publicação a 25.01.2017

\section{Ludmila Mendonça Lopes Ribeiro}

Centro de Estudos de Criminalidade e Segurança Pública (CRISP), Universidade Federal de Minas Gerais Av. Presidente Antônio Carlos, 6627, Pampulha - Unidade Administrativa III, Belo Horizonte, MG - CEP: 31270-901, Brasil

Contacto: ludmila.ribeiro@crisp.ufmg.br

\section{Public Prosecutor: An Old Institution with New Functions?}

In this paper we analyze the results of a quantitative survey conducted with members of the Brazilian Public Prosecutor's Office (MP) in order to answer three questions: Who are the members of the MP? Does the Public Prosecutor deserve the title of Guardian of Democracy? Are the members of the MP promoters of criminal prosecution or true guarantors of a more just society? The results indicate that persons in the MP are from the Brazilian elite, and they focus their actions on the criminal process, assuming the function of guaranteeing broad, collective and homogeneous individual rights.

\section{Ministère Public: vieille institution aux nouvelles fonctions?}

Dans cet article nous nous penchons sur les résultats d'une enquête quantitative réalisée auprès de magistrats du Ministère Public (MP) brésilien afin de répondre à trois questions: quels sont les personnes qui constituent le MP?; le Ministère Public mérite-t-il le titre de "gardien de la démocratie"?; les magistrats du MP sont-ils des promoteurs de l'action pénale ou de véritables agents garantissant une société plus juste? Les résultats obtenus démontrent que les magistrats du MP font partie de l'élite brésilienne, qu'ils focalisent leur intervention sur la procédure pénale, de par l'absorption de la fonction 
In addition, their work is office-based, thus hindering an effective involvement with demands coming from the population. The MP is, thus, an old institution that has not effectively assumed its new functions, granted at the time of re-democratization. Keywords: Brazil; democracy; Public Prosecutor; sociology of law. de garantie de droits diffus, collectifs et individuels homogènes. De plus, ils font prévaloir une intervention bureaucratique au détriment d'un engagement effectif à l'égard des demandes de la population dépendante. Il s'agit donc d'une vieille institution qui n'assume pas effectivement les nouvelles fonctions qui lui ont été attribuées par le rétablissement de la démocratie.

Mots-clés: Brésil; démocratie; Ministère Public; sociologie du droit. 
